\title{
Trojan Horse, Copycat, or Scapegoat? Unpacking the Refugees-Terrorism Nexus
}

\author{
forthcoming in \\ The Journal of Politics
}

\author{
Sara M.T. Polo \\ Department of Government, University of Essex \\ Wivenhoe Park, Colchester CO4 3SQ, United Kingdom \\ sara.polo@essex.ac.uk
}
Julian Wucherpfennig
Hertie School

Friedrichstraße 180, 10117 Berlin, Germany

wucherpfennig@hertie-school.org 


\begin{abstract}
Widespread fear that hosting refugees will mean more terrorism in host states is at the heart of the 'refugee crisis'. Yet, we lack rigorous evidence for such claims. This article theoretically unpacks how and under what conditions transnational refugee movements plausibly lead to different types of terrorist outcomes. Combining original data with a multi-pronged approach involving a treatment-placebo design as well as instrumental variable estimation, we provide systematic and robust evidence that sheds new light on the security implications of transnational forced migration. Our findings challenge the claim that hosting refugees heightens the risk of "importing" terrorist attacks against nationals of host countries, especially in developed countries. However, in these countries refugees themselves are particularly prone to becoming the targets of retaliatory terrorist attacks by natives, driven by fear. Dominant policy responses to the refugee crisis that raise fears and suspicions are therefore not only ill-suited, but potentially counterproductive.
\end{abstract}

Keywords: refugees, transnational forced migration, terrorism, counterterrorism, diffusion, instrumental variable, causal inference

Supplementary material for this article is available in the appendix in the online edition. Replication files are available in the JOP Data Archive on Dataverse (https://dataverse. harvard.edu/dataverse/jop). 
"We cannot let them into this country. This could be one of the great Trojan horses" Donald Trump on Syrian refugees, November 2016

Widespread fear of terrorism is at the heart of the "refugee crisis" that continues to dominate public debates in many countries around the globe. According to several recent large-scale public opinion surveys, vast parts of the population in many countries around the world worry that "there are terrorists pretending to be refugees who will enter [their] country to cause violence and destruction" (Skinner and Gottfried 2017, 24; see Figure 1), and that the "wave of refugees will mean more terrorism" (Wike, Stokes and Simmons 2016, 3). Such views are mirrored among (or possibly spurred by) many policy-makers. Hungarian President Victor Orbán frequently refers to refugees and migrants as "the Trojan horse of terrorism." Similarly, in his "Executive Order Protecting the Nation from Foreign Terrorist Entry" U.S. President Donald Trump explicitly warned of refugees, because they "have been convicted or implicated in terrorism-related crimes.' 11 Even intelligence agencies seem to agree. According to the EU law enforcement agency Europol $(2017,6)$, Jihadist terrorist organizations "already exploited the flow of refugees and migrants to send individuals to Europe to commit acts of terrorism" and "may continue to do so."

Implicit in prevailing fears are doubts over current counter-terrorism capabilities, and that large numbers of refugees will overburden host states' security apparatuses, especially in terms of border policing, and the ability to effectively screen and vet refugees. Such fears have seemingly also fueled a wave of anti-immigrant violence, including high profile attacks against mosques in the U.K., Canada, and New Zealand. Likewise, the German interior minister reported that in 2016 more than 2,500 refugees were victims of anti-migrant violence $\mathrm{L}^{2}$

However, claims that refugees bring with them a heightened risk of terrorism remain far from clear. As pointed out by German Chancellor Angela Merkel, her country "was already

\footnotetext{
${ }^{1}$ http://tinyurl.com/yylcgthp

2 http://tinyurl.com/y452wu6a
} 
FiguRE 1. Percent believing terrorists are pretending to be refugees

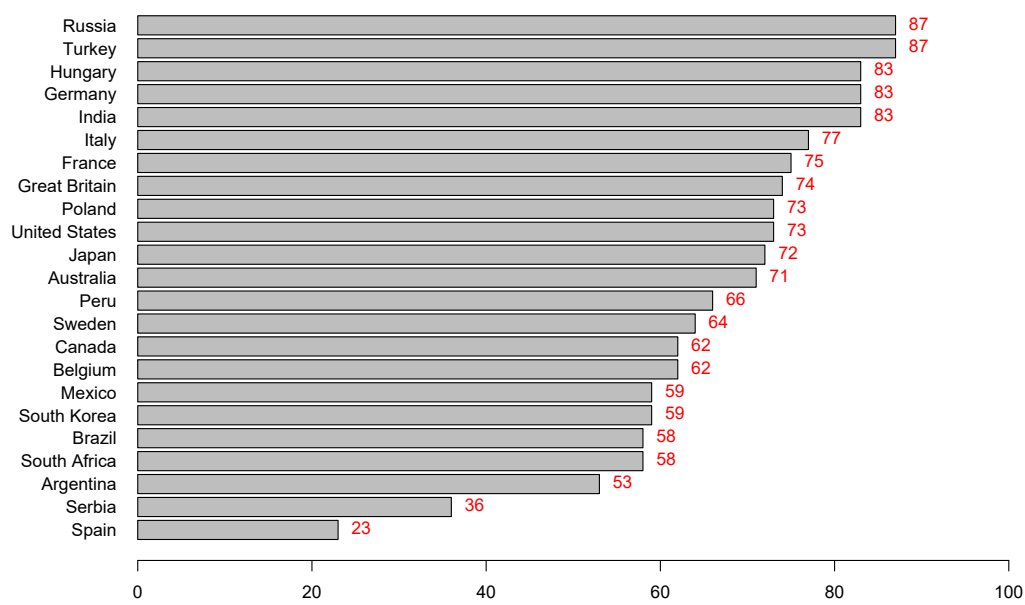

Source: Skinner and Gottfried (2017). Poll conducted in July 2017 among 17,903 adults aged 16-64.

a target for Islamic terrorism before the many refugees came to us.' 3 Indeed, public and political perceptions about the refugee-terrorism nexus could be hampered by cognitive biases. Social psychologists have long argued that humans tend to place undue emphasis on group membership or other individual characteristics of a person, even when significant situational or environmental factors are at work, a fallacy that is known as the ultimate, or fundamental, attribution error (cf. Hewstone 1990; Atran 2003). In this view, the recent incidents would be better explained through the targeted countries' significant roles in international affairs, which render them attractive targets for transnational terrorism (e.g. Savun and Phillips 2009).

Do refugee movements actually 'import' terrorist violence into host states, and if so, how and under what conditions? Despite the immediate policy relevance, there exists a daunting gap in systematic research that could guide policy makers, and inform public debates, especially in the developed world. This paper seeks to fill this gap, both theoretically and empirically. We provide strong and systematic evidence that is squarely at odds with the claim that hosting refugees heightens the risk of terrorist attacks against nationals of host states in the developed world. However, we argue and find that, in these countries, refugees are themselves disproportionately likely to become the targets of terrorist attacks.

3 http://tinyurl.com/y27as56v 
By examining more closely what is being diffused via refugee flows (e.g., people, skills, ideas, or fear), and from which sending locations into which receiving state, we theoretically unpack how and under what conditions transnational refugee movements could plausibly lead to the diffusion of specific terrorist outcomes. Thanks to novel data and a multi-pronged research design we then map these insights directly onto corresponding empirical analyses in a global and up-to-date sample of 161 countries between 1970 and 2016.

We conceptualize three different diffusion pathways. First, in line with the "Trojan horse" claim, we consider whether sizable refugee stocks from countries that are home to transnational terrorist organizations increase the probability of attacks by those organizations in host countries. Second, we examine the claim that refugees may provide logistical and ideological channels that facilitate domestic "copycat" terrorism by groups in host countries. Briefly, we find that refugee stocks from countries that host transnational terrorist organizations (which would have an incentive to foster terrorist agendas internationally) can indeed raise the odds of transnational and homegrown terrorism, but not within developed countries. Finally, we consider domestic responses to the perceived security threats stemming from refugees. We provide strong evidence that refugees and refugees' co-nationals from terror-exporting countries are disproportionately likely to become the targets of (right-wing) terrorism in host states. This pattern of "scapegoating" is particularly pronounced in developed countries.

In our quest to answer whether, how, and under what conditions refugee inflows are linked to the diffusion of terrorism between countries, we advance existing research in several, important ways. Moving closer towards agency, our disaggregated research design (in combination with original data) allows for an explicit investigation of sender-effects whereby refugees from terrorexporting countries - such as Syria, Iraq and Afghanistan-may also carry the baggage of terrorism to refugees' destination countries. Moreover, existing studies are largely confined to the developing world with limited external validity for the developed world, for example by focusing on conditions in refugee camps which are largely absent in Western countries. By contrast, we explicitly consider key differences between developed and developing countries in terms of counterterrorism capabilities, which we refer to as receiver effects. In addition, our 
theoretical approach and research design allow us to examine directly how refugee flows may have varying effects and spread different types of terrorism, including a distinction between attacks by foreign vs. local perpetrators, but also (and especially) terrorist attacks against refugees themselves in host countries. Finally, our approach makes a concerted effort to provide causal, rather than correlational estimates. A treatment-placebo design allows us to tackle selection effects whereby refugees systematically migrate to countries that are more (or less) terrorism prone, even if such confounders are unobservable. Moreover, a sophisticated instrumental variable (2SLS) approach addresses concerns about endogeneity that arise if expectations about terrorism affect refugees' choice of destination country, or if destination countries calibrate their proclivity to host refugees on the basis of fears of terrorist violence.

This research has also critical policy implications. We show that refugees from terrorexporting countries may pose a security risk to host countries, but not everywhere. Paradoxically, the countries where fears of terrorism diffusion are highest, namely developed countries, are those where the security risk for native populations is actually lowest. Put differently, and despite widespread perceptions, developed, Western countries have already taken the necessary measures to minimize the risk of importing terrorism through refugees. Indeed, our estimates show there is little reason to believe that Western countries cannot deal with the refugee issue effectively, nor that denying refuge to those fleeing war and persecution is justified on the basis of concerns about more terrorism. However, refugees seem to suffer from (often) false perceptions of the dangers associated with their presence. This puts refugees at increased risks of becoming the targets of terrorist attacks in host states. Current policy responses to the "refugee crisis" which frequently monger fears are therefore not only ill-suited, but even counterproductive by heightening the overall risk of terrorism. 


\section{Previous Research}

Despite a growing literature on the causes of terrorism, (to the best of our knowledge) only two quantitative studies have examined the relationship between refugee: 4 and terrorism.$^{5}$ Providing important insights, both Milton, Spencer and Findley (2013) and Choi and Salehyan (2013) view terrorism in refugee-hosting countries as the outcome of specific domestic-level processes. These include the radicalization and militarization of refugees due to mistreatment or dismal conditions in camps and changes in the ethnic balance which may exacerbate ethnic rivalries within host states. In contrast to such domestic-level approaches, civil war scholars have argued explicitly that refugees can be a channel by which internal conflict in one state spills over across borders, "transporting" violence through people, skills or ideas from one location to another (e.g. Salehyan and Gleditsch 2006). This view is conceptually in line with prevailing concerns that view refugee movements as a vehicle for terrorism diffusion. However, no study has examined this systematically.

Breaking new ground, Bove and Böhmelt (2016) put forward a diffusion argument that focuses on economic migration (rather than refugees), suggesting that immigrants from countries that experience terrorist attacks could diffuse terrorism to host countries. However, according to our data, 70 percent of all terrorist organizations across the globe exclusively commit domestic attacks ${ }^{6}$ In contrast, transnational terrorist organizations pursue an agenda that (partly) implies the diffusion of terrorism. It is these organizations that can plausibly be expected to infiltrate refugee movements so as to commit attacks abroad, but such organizations

\footnotetext{
${ }^{4}$ Refugees are people forced to flee their country for fear of persecution, war or violence, as opposed to voluntary migrants in search of a better life.

${ }^{5}$ Terrorism is "the premeditated use or threat of violence by individuals or subnational groups against noncombatants to obtain a political or social objective through the intimidation of a large audience beyond the immediate victims" (Enders, Sandler and Gaibulloev 2011, 321) ${ }^{6}$ Domestic terrorism implies that the perpetrators, targets, and location of attacks all belong to the same country (Enders, Sandler and Gaibulloev 2011)
} 
exist in less than 15 percent of all country-years between 1970 and 2016. Yet, existing studies have not systematically examined the possibility of "sender effects" whereby refugee flows that originate from the few localities that are home to terrorist organizations with a transnational agenda are systematically more 'dangerous' than refugees coming from elsewhere.

Moreover, there are large differences in "receiver effects", especially host states' counterterrorism capacities, as well as states' ability to police their borders and screen and vet refugee flows for possible terrorist infiltrations. While previous research suggests that specific state characteristics can mitigate domestic conflict (Braithwaite 2010; Lischer 2005; Wright and Moorthy 2018) receiver effects have generally been neglected in the context of terrorist diffusion via refugee flows. Indeed, many of the above mechanisms linking refugees and violence primarily apply to developing, civil war-prone countries (cf. Lischer 2005; Onoma 2013: Whitaker 2003) and not necessarily to developed countries, which are generally thought to be more effective at shielding themselves from violent spillovers.

Beyond sender and receiver effects, terrorism diffuses in different forms, but existing quantitative studies often rely on overly aggregated counts of terrorist attacks in refugee destination countries. Thus, it remains unclear who the targets of such terrorist violence are. In particular, there has been insufficient attention to the possibility that refugees themselves become the targets of attacks. By disaggregating terrorist outcomes into (1) attacks by foreign groups, (2) domestic attacks, and (3) attacks against refugees, our research uncovers how and under what conditions refugee flows may lead to different types of terrorist attacks in host countries.

Unpacking terrorist attacks by type allows us to contribute to a burgeoning literature highlighting that refugees are also victims of violence in host countries (Fisk 2018; Onoma 2013; Savun and Gineste 2019). While providing insightful contributions, these studies do not consider the targeting of refugees within a diffusion framework and instead emphasize domestic factors, such as refugee settlement patterns and state repression. In contrast, the diffusion literature almost exclusively sees refugees (and migrants) as the perpetrators or vehicles of violence (cf. Bove and Böhmelt 2016). As a way forward, we connect these two literatures by examining the extent to which terrorism diffuses to refugee hosting countries in the form of 
terrorist attacks by local groups against refugees themselves. We theorize this phenomenon as a critical (and hitherto overlooked) pathway of terrorism diffusion and identify specific conditions and mechanisms behind it. In doing so we not only provide a more complete understanding of the pathways by which refugees are linked to the diffusion of terrorism but also respond to Savun and Gineste's $(2019,99)$ call for an explicit focus on the "mechanisms governing civilian violence against refugees in developed" and not just developing "states."

In sum, to date we do not know to what extent terrorism actually diffuses via refugees and the specific actors, processes, and conditions driving it. Without systematic analyses, which identify and test the specific pathways of terrorism diffusion through refugee flows, policies for dealing with refugees, asylum seekers, and terrorist threats are likely to prove ineffective.

\section{Theory}

In this section we develop three theoretical pathways linking the presence of refugees to the diffusion of terrorist attacks in the host country. Before doing so, we briefly outline in more general terms the logic of transnational terrorism, and how its occurrence is shaped by specific incentives of terrorist organizations with a transnational agenda (sender effects), as well as the actions and counter-terrorism capabilities of potentially targeted states (receiver effects).

We define transnational terrorist attacks as attacks where terrorists cross country borders and carry out attacks in other countries. Such attacks are key to achieving important proximate goals of terrorist organizations, including attracting international media attention, advertising a cause to a broad audience, promoting recruitment campaigns, and signaling strength by demonstrating a group's ability to operate and project fear also outside a country's borders (Bapat 2006; Neumayer and Plümper 2010; Hoffman 2006).

However, for terrorist organizations, launching attacks outside of their "home" territory can be difficult, especially when target states are distant, and enforce strict border controls, airport security checks, and sophisticated screening procedures. In this regard, research shows that large, developed democracies are better able to counter transnational terrorism (Enders and Sandler 2011), and that effective protection against transnational terror attacks hinges 
critically on collaborative counter-terrorism measures, including information-sharing, which developed countries are more likely to adopt (Sandler, Arce and Enders 2011). In developing theoretical arguments about how refugee stocks influence the spread of terrorism we build on such receiver effects. In particular, we emphasize that developed countries face a lower risk of terrorist infiltrations due to their greater capacity to police territories and borders, screen refugees and asylum seekers, and implement effective counterterrorism policies.

\section{Refugees as a Trojan horse for transnational terrorists}

We begin by developing theoretically the core logic underlying the claim that refugee movements diffuse terrorism to host states. Carrying out transnational attacks implies that terrorist organizations operate in a relatively unknown territory. Studies of terror networks suggest that terrorist organizations exploit existing social, ethnic, and religious ties to extend their activities to other countries (Sageman 2004). Refugee flows may facilitate this process because they create the potential for physical linkages between populations in terrorists' home country, including members of terrorists' domestic constituency, and the target country. Infiltrating these flows and (ab)using them as a Trojan horse could facilitate the transnational movement of terrorists and enable them to conduct attacks in the host country.

Sizable refugee inflows are also more difficult to screen and may generate administrative overloads, especially when states have limited capacity and resources. Moreover, unlike economic migrants, refugees and asylum-seekers are protected under international law. It may therefore be easier for actual terrorists to exploit large-scale refugee streams to infiltrate and attack foreign countries. Several recent terrorist attacks appear to reflect such a strategy. For example, the suicide bomber who killed ten people on Istanbul's Sultan Ahmet Square in January 2016 had entered Turkey a week earlier as an asylum-seeker from Syria. Similarly, the terrorist who attacked a police station in Paris on the 2016 anniversary of the Charlie Hebdo attack had previously registered as asylum-seeker in Germany (Schmid 2016, 44).

Thus, refugee streams can facilitate the direct migration of terrorists from the refugees' home country to the host country. However, we emphasize that the risk stemming from 
refugees based on the Tojan Horse argument is conditional on the existence of terrorism in the sending countries. Put simply, where there is no terrorism in the refugees' home countries, the arrival of refugees can hardly transport terrorism. Among others, this applies to instances where refugee stocks are driven by individual persecution. In this view, refugees fleeing from crime, gang and drug violence in Central American countries (such as Honduras, El Salvador or Guatemala) are unlikely to be diffusers of terrorism, precisely because these countries do not have transnational terrorist organizations. In short, refugees from countries without transnational terrorist organizations should have no effect on the diffusion of transnational terrorism to the host country ${ }^{7}$ We therefore articulate our Trojan horse hypothesis that highlights important sender effects:

H1a Refugee stocks from countries that are home to transnational terrorist organizations increase the risk of transnational terrorist attacks by those organizations in host countries.

Moreover, countries differ in their abilities to protect themselves by deterring or foiling attacks, cooperatively screening refugees, and sharing counter-terrorism intelligence. Developed countries have a significant advantage in this regard due to their superior capabilities and resources. Moreover, developed countries typically uphold much tighter screening and vetting procedures. For example, to prevent terrorist infiltrations, Germany conducts highly sophisticated identity checks which include image and speech biometrics. In Italy, where most refugees arrive by sea, the Interior Ministry has implemented a large-scale aeronaval patrolling in which the Army, the Navy, the Finance Police, the Coast Guard, and Frontex (i.e. the European Border and Coast Guard Agency) are involved; furthermore, through the adoption of specific protocols aimed at preventing the infiltration of radicalized individuals, the Italian government has been able to identify almost all the asylum seekers and refugees that arrived

\footnotetext{
${ }^{7}$ Terrorism in the host country could also emerge from purely domestic processes, e.g. ethnic imbalance or resource competition between refugees and locals. Our empirical strategy controls for these alternative processes and compares them to diffusion pathways.
} 
in the country $\left.\right|^{8}$ The screening and vetting procedures that developed countries implement are conducted either in the refugee sending countries through resettlement programs, ormuch more commonly - upon arrival. Indeed, according to the UNHCR, resettlement only represents a small minority of developed countries' total refugee intake $!^{9}$

In contrast, we expect less developed countries to face higher risks of terrorist infiltrations due to a limited capacity to effectively police borders, screen refugees and asylum seekers, as well as insufficient counterterrorism measures. For example, Kenya's inability to effectively police its borders and the Dadaab (Somali) refugee camps appears to have facilitated al-Shabaab's infiltrations and terrorist attacks ${ }^{10}$ Therefore, we further narrow down the conditions under which we expect the Trojan horse mechanism to hold by highlighting important receiver effects:

H1b Refugee stocks from countries that are home to transnational terrorist organizations increase the risk of transnational terrorist attacks by those organizations, especially in less developed host countries.

\section{Domestic terrorists as copycats}

Large-scale arrivals of refugees can also impact the behavior of domestic groups in host states by facilitating their own adoption of terrorism. There is evidence that terrorist activities by groups abroad can influence terrorism at home (i.e. 'home-grown' terrorism) through emulation and demonstration effects $($ Polo 2020). However, domestic groups at home are not able to plan and execute terrorist attacks at will, even when inspired to do so by events abroad.

${ }^{8}$ https://tinyurl.com/vnjpftg

${ }^{9}$ https://tinyurl.com/tjtu2wh. Germany in 2018 hosted more than 1 million refugees, with only 3219 resettlement arrivals in that year. Moreover, the total number of refugees resettled in Germany between 2000 and $2018(11,426)$ is only 1\% of the number of refugees hosted in Germany in 2018 (UNHCR data).

${ }^{10}$ https : //tinyurl.com/vquwgbc 
Groups' choices are constrained by access to resources such as weapons, personnel, training, and experience; and these resources are crucial to orchestrating effective terrorist campaigns (e.g. Braithwaite and Chu 2018). Thus, similar to the "Trojan horse" mechanism, refugees may create direct, physical connections which can facilitate the movement of seasoned terrorists, including foreign fighters, to host countries. Such linkages provide opportunities for domestic groups who hold grievances against the state to establish contacts with terrorist organizations, learn tactics, gain access to terrorism-specific capital, and even establish alliances. This will, in turn, boost domestic groups' capabilities since networked organizations are generally more active in carrying out terror attacks and also more lethal (e.g. Asal and Rethemeyer 2008).

Consider, for example, the recent case of Lebanon. As ISIS increased its presence in Lebanon, also by infiltrating several refugee camps (Schmid 2016, 34), new homegrown Sunni terrorist organizations emerged in the country, such as Liwa Ahrar al-Sunna and Jund alSham for Tawhid and Jihad, the latter operating out of the Ain Al-Hilweh refugee camp. These organizations have increased their capability by cooperating, and even carrying out joint attacks, with ISIS. In 2014 the total number of domestic terrorist attacks in Lebanon reached its highest peak since 1983. Moreover, refugee flows are bi-directional. While actual refugees seek to flee conflict zones, disenfranchised domestic groups in the host may use these routes (in the 'opposite' direction) to join existing conflicts, receive terrorist training, and carry out terrorist attacks upon their return home. Several domestic terrorist attacks in both Kenya and Lebanon have been linked to returning fighters from the conflicts in Somalia and Syria 11 This discussion leads to specific empirical implications, stated in the following hypothesis:

H2a Refugee stocks from sending countries that are home to transnational terrorist organizations increase the risk of domestic terrorist attacks in host countries.

As before, we expect the effects of refugee stocks to be further conditioned by the host state's ability to police, detect, deter or foil attacks - which should be more extensive in developed

\footnotetext{
${ }^{11}$ https://tinyurl.com/uw72czp; https://tinyurl.com/qpwatem
} 
countries, precisely because these countries are better able to interrupt the channels that (potentially) connect domestic groups with transnational resources that facilitate terrorism. Accordingly, we formulate the following hypothesis:

H2b Refugee stocks from sending countries that are home to transnational terrorist organizations increase the risk of domestic terrorist attacks in host countries, especially in less developed countries.

\section{Refugees as scapegoats}

Finally - going beyond the extant scholarly work and much of the public debate - we argue that the relationship between refugees and the diffusion of terrorism is also influenced by the responses of local citizens. Large-scale arrivals of asylum seekers and refugees can generate hostility and perceptions of insecurity among local communities. At the same time, this is only one possible reaction to refugee presence. Although refugee inflows impose additional pressure on domestic welfare systems and resources, citizens in host states have often demonstrated a high sense of solidarity and a willingness to help those fleeing conflict and persecution. Such positive responses have recently been observed across several European countries.

However, there are specific situations in which fear trumps solidarity and triggers violent responses from local groups. Specifically, when refugees come from terrorist conflicts, refugees themselves are more likely to be perceived as a major security threat. Fear that terrorists could exploit refugee streams (i.e. the Trojan horse mechanism) makes refugees a prime target of violent attacks since they are regarded as a possible vehicle for terrorist violence, although an involuntary one. Such attacks on refugees are often terrorist in nature since they are meant to intimidate and send a message to other refugees (and migrants), to terrorist organizations wishing to infiltrate refugee streams, and to domestic authorities (cf. Hoffman 2006). When refugees are scapegoated for a perceived terrorist threat, terrorism against refugees can take the form of an indirect retaliation. This further increases terrorism in the host country.

For example, after 2015 Germany accepted hundreds of thousands of refugees, mainly from Syria, Iraq and Afghanistan. Subsequently, the German Interior Ministry documented a sub- 
stantial, nationwide increase in attacks against refugees and asylum seekers. In 2016, when Germany was targeted by several transnational terrorist attacks, hundreds of asylum seekers and refugees were injured in more than 3,500 retaliatory attacks on them and their shelters. ${ }^{12}$ Observers note that these attacks were often spurred by fear-mongering propaganda by the far-right party AFD. In a 2017 publication the party stated that "recent attacks perpetrated by recently immigrated asylum seekers [...] show that uncontrolled mass-migration increases the risk of terrorism.' ${ }^{13}$ Likewise, a party official remarked that "[b]urning asylum shelters are not an act of agression.' 14

Based on our fear and retaliation argument, terrorism is not directly "exported" out of ongoing conflicts but emerges from fear of a perceived terrorist threat associated with the arrival of refugees. Thus, terrorism is not only the threat but also the response, which takes the form of attacks by local groups against refugees as well as migrants with ethnic or religious identities similar to those of the refugees. Moreover, hostility toward "threatening out-groups is felt regardless of whether threat is defined as a widely acknowledged external force or a subjective, perceived state" (Huddy et al. 2005, 594). Put differently, increased prejudice and violence against threatening out-groups can occur not only where threats are "real" but also where they are potential or simply perceived. Therefore, we expect violent attacks against refugees to occur not only in less developed countries, which are objectively more prone to transnational terrorism, but also in more developed countries where terrorism is a more exceptional phenomenon. If anything, perceptions of security threats and vulnerability are likely to be exacerbated in developed countries, partly because of the amplifying effects of the media and the incentives of populist politicians. Indeed, the ways in which the security implications of the "refugee issue" are covered in local media and exploited in the political debate can significantly contribute to fueling public fears toward refugees and may inadvertently place

\footnotetext{
12 https : //tinyurl.com/vd6d3yr

${ }^{13}$ https://tinyurl.com/sxkwvpm

${ }^{14}$ https : //tinyurl . com/u69w98w
} 
them at grave risk 15

However, we emphasize that this diffusion effect is inherently conditional. Although the presence of refugees can be destabilizing for multiple reasons (e.g. Savun and Gineste 2019), we expect local groups to become more likely to carry out terrorist attacks against refugees in the presence of specific factors that create fear for personal security and desire for retaliation, especially transnational terrorism in the refugees' home state. As several studies have shown, those external threats that specifically involve the potential for physical harm, such as terrorism, increase one's sense of vulnerability and motivate action designed to minimize personal risk, including punitive action against the perceived source of the security threat (cf. Huddy, Feldman and Weber 2007; Huddy et al. 2005). Refugee flows from terror-exporting countries are much more likely to be perceived as dangerous and this increases the likelihood that refugees themselves become a scapegoat.

Based on the above discussion, we state the following hypotheses:

H3a Refugee stocks from countries that are home to transnational terrorist organizations increase the risk of terrorist attacks against refugees in host countries.

H3b Refugee stocks from countries that are home to transnational terrorist organizations increase the risk of terrorist attacks against refugees in host countries, especially in developed countries.

\section{Data and Research Design}

Our three sets of hypotheses differ with respect to perpetrators (domestic or transnational groups) and targets of terrorism (natives or the refugees themselves). Thus, we construct three outcome variables, each reflecting the observable and mutually exclusive implications of the theoretical pathway. Our primary data source is the Global Terrorism Database (GTD;

\footnotetext{
${ }^{15}$ Despite developed countries' capabilities, politicians have little incentive to invest resources in countering attacks against refugees since the latter are not voters.
} 
LaFree and Dugan 2007), which provides global coverage of terrorist attacks for the period 1970 to 2016, and is widely considered the most comprehensive dataset on terrorism.

Although the GTD indicates whether attacks have some transnational component, a key limitation for our purposes is that GTD does not provide the nationality of the perpetrators of terrorist attacks. Moreover, GTD considers attacks as transnational even if they occur in the country of origin of the perpetrator, including attacks against foreigners (refugees) which are perpetrated by natives. In contrast, the Trojan horse pathway strictly implies the movement of terrorists across borders, and that natives are the targets of their attacks.

Overcoming conceptual conflation of this type, we provide a novel dataset - the GTDhomes - which codes the "home countries" (i.e. main base of operation) of all 741 terrorist organizations which have conducted at least one transnational attack as per the GTD. To code "home countries" we rely on two criteria. First, we consider an organization's main base of operation. For countries in civil war we use the government against which the group is fighting as an indicator. For other organizations we consider the country in which a group primarily operates. Second, we consider the organization's membership, especially from which population/s the group primarily recruits as well as claims on behalf of specific ethnic groups. For most organizations (92 percent) we identify a single primary home state. However, some organizations, such as al-Qaida in the Islamic Maghreb and ISIS, are fully established in multiple countries. ISIS has also a few local branches (e.g. in Libya, Egypt and Afghanistan) which are coded as exclusively based in the country in which they were formed and operate. We also allow for changes in a group's home country over time, e.g. ISIS in Iraq and Syria between 2013 and 2016.16 Thus, the GTD-homes data allow us to study whether refugees flee from places with transnational terrorist organizations and whether attacks originate from the same places from which refugees flee, thereby avoiding problems of over-aggregation.

Our unit of analysis is the country-year, covering 161 countries for the period 1970 to 2016. For the Trojan horse hypotheses our dependent variable is the number of transnational attacks

\footnotetext{
${ }^{16}$ See the Supporting Information for more details on the coding rules.
} 
which take place in each country-year, and which are perpetrated by foreign groups. For the copycat hypotheses we use a count of all domestic attacks taking place in the country-year and which are perpetrated by domestic terrorist groups against domestic targets ${ }^{17}$ Finally, for the scapegoat hypotheses we combine data on the nationality of targets and target types from the GTD with data on the countries of origin of the refugees hosted in each country-year. This allows us to extract the number of attacks which target refugees or their co-nationals.

Data on refugee stocks, including the countries of origin and countries of asylum, are derived from the UNHCR database (UNHCR 2016) ${ }^{18}$ Combined with our GTD-homes dataset, we are thus able to capture whether (1) transnational terrorist attacks coincide with refugees' countries of origin, and (2) the refugee sending country also happens to be home to terrorist organizations with a transnational agenda (as per our GTD-homes coding), so that refugee stocks could plausibly be infiltrated to 'export' people, skills, ideas, or fear related to terrorism.

We use the country-year (i.e. potential host states) as our unit of analysis, focusing on the total stock of refugees, precisely because claims linking refugees to transnational or domestic terrorism emphasize host countries' presumed inabilities to screen, vet, or integrate large numbers of refugees due to administrative overload and insufficient counterterrorism capabilities. Similarly, our argument about scapegoating also emphasizes the perceived incapacity to deal with large numbers of refugees, which could hardly be reflected in a dyadic design ${ }^{19}$

However, in line with our theoretical arguments, we introduce an important distinction depending on the type of country from which refugees fled. This gives rise to a treatmentplacebo design. Specifically, the claim that refugee flows lend themselves as a vehicle which

\footnotetext{
${ }^{17}$ An ideal extension would be to unpack domestic attacks based on groups' ideologies, but no such data currently exist.

${ }^{18}$ These data do not include refugees resettled into third countries through official resettlement programs. Moreover, resettled refugees comprise less than one percent of global refugees, contrary to common belief.

${ }^{19}$ In the Supporting Information we provide dyadic results consistent with our main findings.
} 
transports foreign terrorists (H1), resources and ideas (H2), and fear (H3) to host countries quasi-conceptually requires the presence of transnational terrorist organizations at the origin of the flow (treatment). Conversely, countries which are free from transnational terrorist organizations quasi-conceptually cannot export terror through refugee flows (placebo). Thus, we distinguish between refugee stocks originating from countries with and without transnational terrorism 20

This treatment-placebo design has several advantages. First, it allows us to examine sender effects and distinguish refugee flows based on conditions in origin countries and incentives of terrorist groups operating therein. Second, it allows us to control for selection effects. If refugees select host countries based on some characteristic that also affects the outcome (e.g. levels of terrorism), this selection effect should apply to all refugee stocks regardless of origin, precisely because the overwhelming majority of all refugees are civilians. The 'placebo' refugee variable accounts for such possible selection effects, even if these are (otherwise) unobservable. Finally, the placebo variable captures domestic conflict processes between refugees (per se) and natives. For example, if economic competition between refugees and locals incites terrorist violence, then it does not matter whether refugees came from terror exporting places. In this case violence arises locally, and is not diffused from other places. Consequently, we also present Wald tests that examine the difference between the effects of the treatment and the placebo. Any difference can then only be driven by diffusion processes along the lines of the three diffusion pathways. Therefore, our design does not assume that 'placebo' refugee stocks do not have an effect on the outcomes or that the treatment dominates the placebo. Instead, we explicitly test and provide evidence for this conjecture in all of our empirical models.

\footnotetext{
${ }^{20}$ We use the logged count for all of these (adding one to avoid the log of zero) and a threshold of at least one transnational attack originating from the sending country to define the treatment condition, since any higher threshold would dilute the placebo. Only $1.4 \%$ of all terrorexporting country-years exports just one attack overall, with an overall mean of 96 attacks, and a mean of 111 among those countries that also send refugees.
} 
To test the hypotheses that focus on static receiver effects (i.e. H1-3b) we split the sample on the basis of OECD membership, which we use as shorthand for a number of characteristicsincluding development, membership and influence in international organizations, and most importantly a more extensive counterterrorism apparatus.

We also include a number of relevant control variables. Logged GDP per capita as well as population size are obtained from the World Development Indicators. All else equal, more developed and larger countries should make more attractive targets for transnational attacks (e.g. Savun and Phillips 2009). We also include a non-linear parameterization for democracy, through the PolityIV index, and its squared term, because previous research has postulated a curvilinear relationship between democratic institutions and terrorism (e.g. Gaibulloev, Piazza and Sandler Forthcoming). Dummy variables for civil and interstate, based on the UCDP/PRIO Armed Conflict Database (Gleditsch et al. 2002), account for armed conflict being the strongest predictor for terrorism in a country (Smith and Zeigler 2017). We also use the UCDP/PRIO data to construct a binary indicator for external intervention in intrastate conflicts, capturing whether the country is currently providing troop support in an ongoing civil war elsewhere in the world (Savun and Phillips 2009). Finally, we include two spatial lags (weighted sums based on inverse logged distance) to account for neighborhood effects, i.e. proximity to civil war countries, as well as proximity to countries which host transnational terror organizations. A table with summary statistics is given in the Supporting Information.

\section{Results}

We use OLS models with logged dependent variables. Country and time fixed effects account for unobserved between-country variation that is time-constant as well as global temporal trends and shocks: ${ }^{21}$ These additional intercepts, together with the control variables, guard against the fundamental/ultimate attribution error, whereby humans tend to disregard con-

\footnotetext{
${ }^{21}$ We cannot use a count model (e.g. Poisson or negative binomial), since analogous fixed effects models for such link functions do not exist (e.g. Allison 2009).
} 
textual or situational factors at the expense of individual idiosyncrasies. To accommodate potential issues of interdependence we use robust standard errors clustered by country.

Trojan horse. The results for the Trojan horse hypotheses are given in Table ??, Models 1-3. The dependent variable is the number of transnational attacks. Our key independent variable, or treatment, is the logged number of refugees fleeing from countries with transnational terrorism. We also include the number of refugees from places that are not home to terrorist organizations with a transnational agenda, and this constitutes our placebo. This distinction is important because the Trojan horse hypothesis holds that terrorists active in sending countries infiltrate refugee flows. Plausibly, this can only work if transnational terrorist organizations are actually active in sending countries ${ }^{22}$ We therefore expect the coefficient for the placebo refugee variable to be close to zero. If the coefficient were distinguishable from zero, this would indicate that there are omitted variables that correlate with both refugee flows and transnational terrorist attacks in host countries, i.e. selection effects. However, even if these effects were non-zero, we would still be able to estimate the effect of the treatment; this would then be the difference between the treatment condition and the placebo. We therefore conduct Wald tests that test whether the coefficients for the two refugee variables are statistically different. We report the associated $p$-values at the bottom of the table. Due to limited space, we focus on the interpretation of the key variables.

Model 1 in Table 1 tests H1a. The coefficient for refugees from terrorism-hosting countries is positive and significant, while the coefficient for refugees from terrorism-free countries turns negative and is also significant. Since both the dependent and the main independent variables are log-transformed, the coefficients can be interpreted as elasticities. Accordingly, a 1 percent change in the number of refugees from countries that harbor transnational terrorist organizations increases the number of transnational terrorist attacks in the host country by

\footnotetext{
${ }^{22}$ Below we explicitly address the possibility that refugee flows are infiltrated elsewhere, on the route to destination countries.
} 


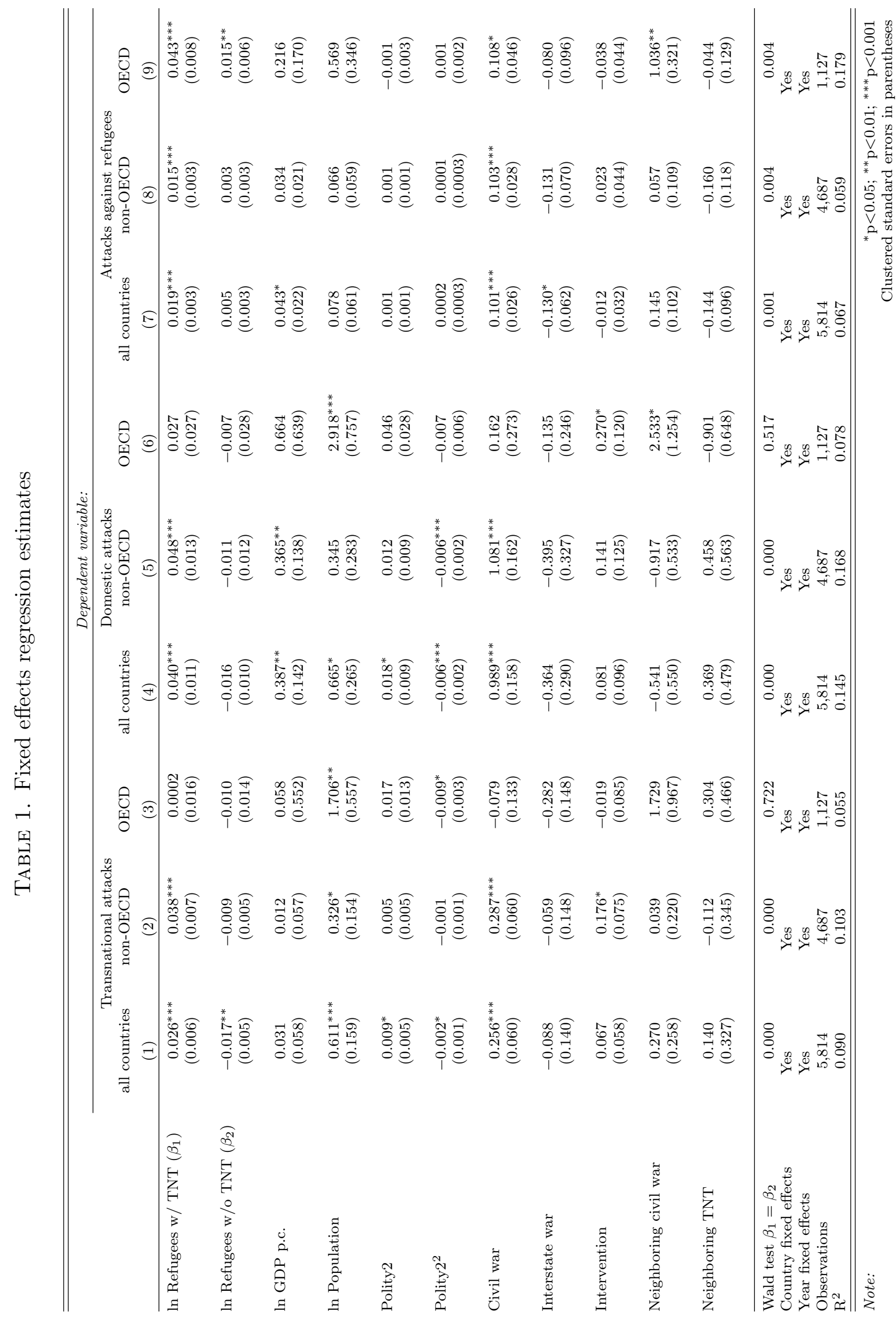


.026 percent. This provides some evidence in favor of the Trojan horse hypothesis. Testing H1b, Models 2 and 3 divide the sample by OECD membership. In line with our expectations, we find that refugee stocks raise the probability of transnational terrorist attacks if the host country is not an OECD-member and if the refugees' home country is home to transnational terrorist organizations. By contrast, within the developed world the effect of refugees is not distinguishable from zero and also not distinguishable from the placebo effect. In short, a positive and significant effect of refugee stocks from countries with transnational terrorism exists only in non-OECD countries.

Copycat. Turning to the hypotheses about 'home-grown' terrorism, recall that the dependent variable denotes domestic attacks. The results are also reported in Table 1, Models 4-6. Similar to the Trojan horse results, we find that refugees from countries with transnational terrorism increase the risk of domestic terrorism, but this effect is again limited to developing countries. OECD countries appear largely immune from the risk of emulation in domestic terrorist attacks through refugees. The coefficient for the treatment refugee variable is indistinguishable from zero. Moreover, and in line with our expectations, placebo refugee stocks (i.e. refugees from countries that are free from transnational terrorism) have no significant effect on the risk of domestic terrorism in both developed and developing countries.

Scapegoat. Finally, we examine the question of whether and under what conditions refugees are themselves likely to be targeted in host states. Thus, Models 7-9 in Table 1 examine whether refugees (or citizens of refugees' origin countries) are disproportionately likely to become the targets of terrorist attacks in host countries. To this effect we rely on a similar setup as before, but with a dependent variable that counts these attacks. Again we distinguish between refugees from countries with significant transnational terrorism and refugees from countries with little or no such terrorism. In fact we argued that refugee stocks from countries with transnational terrorism are more likely to generate perceptions of security threats among native populations. This, in turn, increases the likelihood of attacks against refugees (H3a). Model 7 confirms this. The coefficient for refugees from countries with transnational terrorism 
is almost four times the magnitude of that for the placebo refugee stocks (and the latter is also not statistically significant). A Wald test confirms that the two are statistically different, suggesting that this effect goes beyond mere xenophobia (which would be picked up by the placebo).

Our argument further suggests that due to the exceptional character of terrorism in developed countries, and sensationalist media coverage thereof, fear and retaliation should be particularly pronounced in developed countries. Models 8 and 9 (Table 1) examine this more in detail. The coefficient for refugees from countries hosting transnational terrorist organizations is around three times larger for the OECD sample as compared to the non-OECD sample (while both are statistically significant). This indicates that retaliatory attacks against refugees are particularly frequent in the developed world.

\section{Probing the scapegoat mechanism}

To further demonstrate the security-driven mechanism behind attacks on refugees we conduct additional analyses taking into account a country's recent memory of severe transnational attacks (see Table A2 in the Supporting Information). We introduce a variable indicating

the maximum severity of any transnational attack in the country during the previous five years. We then interact this variable with the refugee variables. Figure 2 illustrates the resulting effects, distinguishing between non-OECD and OECD countries. In countries that previously suffered from severe transnational terrorist attacks refugees are much more likely to be "punished." Specifically, as the severity of prior terrorism increases so does the effect of refugee stocks on retaliatory attacks against refugees. This effect is directly related to fears of transnational terrorism, since it only pertains to refugees from countries with transnational terrorism. Other refugees do not influence terrorist attacks even when taking into account previous terrorism in the host country. Moreover, such security-driven retaliatory effects are particularly strong in OECD countries. Overall, we find robust and systematic evidence that refugees from countries with transnational terrorism are disproportionately more likely to become the targets of terrorist violence in host countries, especially in the developed world. We 
non-OECD

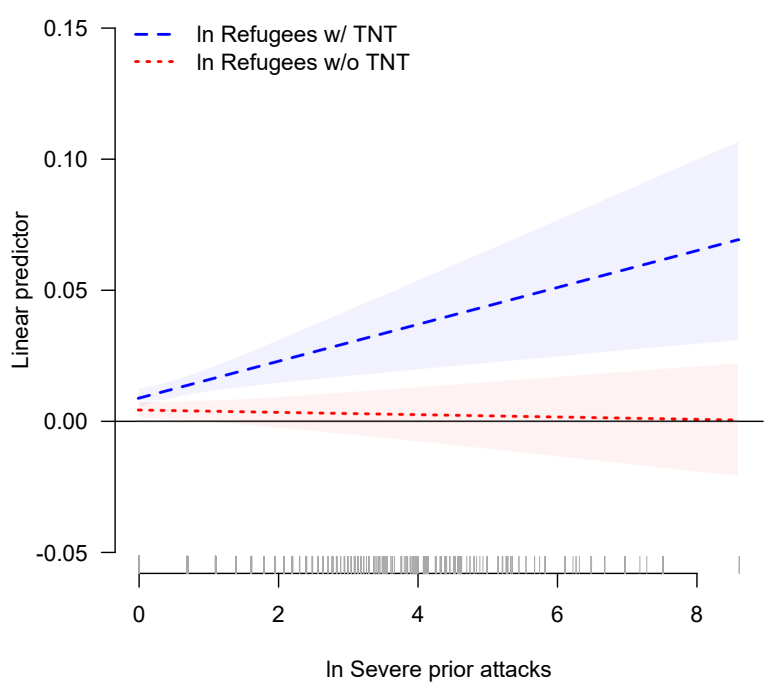

OECD

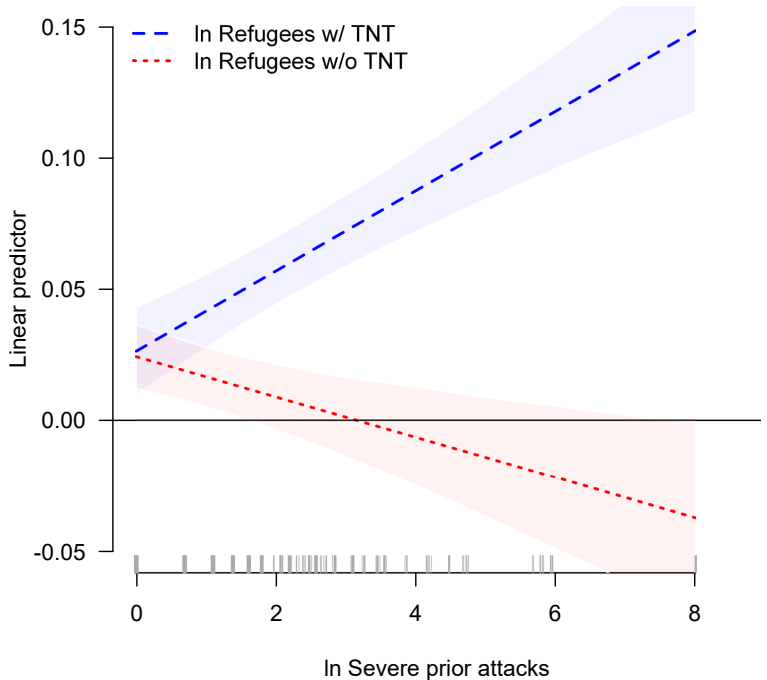

FIGURE 2. Attacks on refugees conditional on history of severe transnational terrorism

also examine whether the targeting of refugees is related to refugees' engagement in violence against local civilians (data from Savun and Gineste 2019). We find that this is not the case; refugees perceived as dangerous are more likely to be targeted regardless of their actual involvement in violence (Table A3). This provides additional evidence in support of a securitydriven scapegoating.

\section{Alternative explanations and robustness}

\section{Placebo outcomes}

The empirical results so far have provided strong support for our theoretical argument. Here we discuss a series of additional tests (reported in the Supporting Information) which further scrutinize our theory and results by examining the effect of refugee stocks (treatment and placebo) on a terrorism outcome that should be theoretically unrelated to, and unaffected by, refugee flows. This placebo outcome analysis allows us to rule out additional unobserved confounders which may be driving the results, as well as alternative pathways linking refugees 
and terrorism 23

Unobserved confounders (e.g. regional instability, conflict hot-spots, etc.) may make a country not only more likely to host refugees but also a more attractive target for terrorist attacks, even though terrorists do not reach their target countries by infiltrating refugee flows, and so the two are not causally related ${ }^{24}$ There is also a potential for networked origins of violence. It may be the case that terrorists infiltrate refugee flows in countries other than the terrorists' home state, for instance if terrorist groups travel to refugee origin countries or infiltrate refugee flows along the route to the destination countries. To address these possibilities we generate a placebo outcome of terrorist attacks in the host country by organizations based in countries whose refugees, if any, are not currently present in the host country. If the effects of refugee stocks on this placebo dependent variable mirror those for the actual dependent variable (see Table 1) then it is likely that some other factors are jointly driving refugee movements and terrorist attacks in the host. Models 1-3 in Table A4 show that this is not the case. The coefficients for our treatment refugee variable are either not statistically significant or negative, and also indistinguishable from the placebo refugee variable. These results lend additional credibility to our argument and theorized pathway.

Our theory further posits that refugee stocks from terror-afflicted countries are more likely to be perceived as a threat and therefore be targeted by local groups. However, it may be the case that xenophobia, a generic hostility toward all foreigners, is in fact driving the results. Our placebo dependent variable for H3 captures terrorist attacks against all other foreigners thereby excluding individuals from refugees' home countries. If we find that the effects of refugee stocks on this dependent variable are the same as those in the main analyses then simple xenophobia and not a perceived threat to security could be driving the attacks on refugees. The results of these analyses are reported in Models 4-6 in Table A4. The effect of

\footnotetext{
${ }^{23}$ We are conceptually unable to devise a placebo outcome for domestic terrorism.

${ }^{24}$ Recall that the treatment/placebo refugee variables allow us to rule out selection effects concerning refugee destinations.
} 
almost all our refugee variables is negative and not significant. Together with our previous analyses on the security drivers of attacks against refugees, these findings help us rule out the alternative explanation that refugees, and migrants from refugee origin countries, are targeted simply out of xenophobia.

\section{Instrumental variable estimation}

A remaining concern holds that refugee movements and terrorist attacks might be simultaneously determined, for example if refugees choose destination countries partly on the basis of expectations about terrorist violence, or if the threat of terrorism driven by refugees affects destination countries in their proclivity to host refugees in the first place. In this case, it is difficult to discern the direction of causality, and the validity of our results could potentially be undermined. Thus, we develop a novel instrumental variable approach 25

The task of the instrumental variable approach is to explain refugee movements in a way that is independent of terrorism. We follow a three-step approach that is inspired by seminal work that addresses analogous challenges pertaining to the effect of trade on economic growth (Frankel and Romer 1999; Feyrer Forthcoming), but also migration (e.g., Docquier et al. 2016). Specifically, we first build a theoretical gravity model to predict time-varying refugee movements between countries (a dyadic "zero-stage" model) in a way that is independent of terrorism in host countries (rather than optimizing prediction per se). We then aggregate the resulting dyad-level predictions by host-country year so as to arrive at a generated instrument that meets the exclusion restriction and can be used to estimate a conventional 2SLS model.

The idea behind the zero-stage gravity model is to use time-varying push and pull factors in sending and host countries, weighted by the proximity (gravity) between them, in order to explain time variation in refugees within dyads. Specifically, we include interaction effects between distance and push/pull factors (detailed below), while also including dyad and year fixed effects. Importantly, under constant geography these zero-stage fixed effects are entirely

\footnotetext{
${ }^{25}$ Due to space constraints, we provide an extended discussion in the Supporting Information.
} 
absorbed by host country and year fixed effects in the first and second stage regressions, as are pull factors provided they are also included as covariates. Thus, by design these cannot violate the exclusion restriction, and so identification is achieved squarely through the interaction terms that generate variation across time that is not ruled out by the fixed part of the first stage model. Finally, for push factors that trigger refugees in the zero-stage, we need to rule out that any such driver of refugees is related to the occurrence of terrorism in specific destination countries in the current year.

With these considerations in mind, we use a sample of all directed dyads with a maximum distance of 3,000 kilometers between their capitals, or where the destination country is an OECD country (any distance), resulting in 330,505 directed dyad-years. We then use a relatively slim specification that involves two measures of (social) distance (log distance between capitals and shared language (Mayer and Zignago 2011)) ${ }^{26}$ one pull factor (the host country's Polity2 score), as well as one push factor (interstate war in the origin country not involving the destination country). These variables are chosen to reflect the well established finding that refugee movements are constrained by physical distance but facilitated by connections of shared language (e.g., Neumayer 2004; Moore and Shellman 2007). We use Polity2 as a proxy for the attractiveness of the host country (Neumayer 2004). Finally, the push factor capturing war not involving the host country is derived from the UCDP/PRIO dataset Gleditsch et al. 2002) and denotes a total of 7,230 dyad-years in which the origin country is involved in interstate war (with at least 25 battle-related death in a calendar year) with one or more country other than the host country. The idea is that interstate war generates refugees Neumayer 2005), while the absence of the host country as a party to the conflict does not raise its current attractiveness for terrorist activity originating from the sending country. ${ }^{27}$ Again, note that

\footnotetext{
${ }^{26}$ We do not use data on refugees' transborder ethnic kin (Rüegger and Bohnet 2018) because these are limited to a $950 \mathrm{~km}$ radius, thereby excluding most refugees in OECD countries. ${ }^{27}$ Using natural disasters in origin countries in place of the war dummy yields substantively similar results (results not shown).
} 
we simply need to rule out that the host country becomes a more attractive target while the origin country is at war, rather than in general (i.e. time-invariantly, which is accounted for through the fixed effects).

The results of the zero-stage are given in the Supporting Information, Table A5. Refugees are more likely to flee from war at home, while a higher Polity2 score renders a given destination country more attractive (although this is not statistically significant). In line with a gravity logic, these effects decrease with increasing geographic distance, and are amplified by shared language. The model yields an $R^{2}$ of .6, indicating a relatively good fit for this particular sample.

Next, we use the dyadic predictions of this zero-stage in combination with the GTD-homes data, so as to arrive at two instruments that can be used in 2SLS model akin to Table ??. Table A6 in the Supporting Information provides the results for the first stage. Models 1 and 2 invoke our full global sample and predict refugee stocks from countries with and without transnational terrorist organizations present in the origin countries, respectively. Models 3 and 4 denote the respective first stages for the non-OECD sample, while models 5 and 6 provide the estimates for the OECD sample. Strikingly, the instruments derived from the zero-stage are powerful predictors of refugee stocks across all models, as suggested by F values well above the conventional threshold of $102^{28}$ This provides considerable confidence that we do not have a weak instrument problem (Sovey and Green 2011) 29

Having instrumented for refugee movements in a way that meets the exclusion restriction and avoids weak instrument problems, Table ?? provides the estimates of the second stage analogous to those in Table ??. These are in line with our previous results: we find that refugees from countries that host transnational terrorist organizations increase the risk of

\footnotetext{
${ }^{28}$ Because we have more than one endogenous variable, we report more conservative conditional F statistics (Sanderson and Windmeijer 2016).

${ }^{29}$ Using a generated instrument does not affect the standard errors of the 2SLS estimator (Wooldridge 2010, 123-4).
} 
transnational and domestic terrorist attacks, but this result only holds for non-OECD countries (models 1-6). By contrast, there is a strong positive effect whereby refugees themselves become the targets of terrorist attacks in destination countries, especially in OECD countries (models $7-9) \longdiv { 3 0 }$

The estimates from our instrumental variable approach make a concerted effort of causal identification, going beyond mere correlation. While the 2SLS estimator can recover the local average treatment effect (LATE), i.e. the effect for the subpopulation affected by the instruments, the setup of the zero stage equation uses as the exclusion restriction a very general push factor (interstate war not involving the destination country) that is widely acknowledged to be a major driver of refugee movements (Neumayer 2005). Thus, we conjecture that our LATE estimates actually cover a large share of the total population of refugees, and are thus broadly applicable.

Finally, skeptics might remark that differentiating predicted refugee counts depending on the presence of transnational terrorist organizations in origin countries reintroduces endogeneity. However, while transnational terrorist organizations might increase the overall (global) level of terrorist activity, this is ruled out by the fact that we include year fixed effects in all models. Indeed, the mere presence of a transnational terrorist organizations in a given origin country by itself says little about why any particular destination country should become the target of their activities during that year ${ }^{31}$

\section{Robustness}

In addition to placebo outcomes and instrumental variable analyses, our main results are robust to various alternative specifications and estimations. These additional analyses are reported in the Supporting Information. Here we provide a brief summary.

First, it may be the case that refugee stocks from countries with transnational terrorism

\footnotetext{
${ }^{30}$ Since the instruments for the treatment and placebo vary in strength (and hence also the corresponding standard errors), Wald-tests must be interpreted with care in this setup.

${ }^{31}$ Recall that all time-invariant channels are blocked through dyad and country fixed effects.
} 


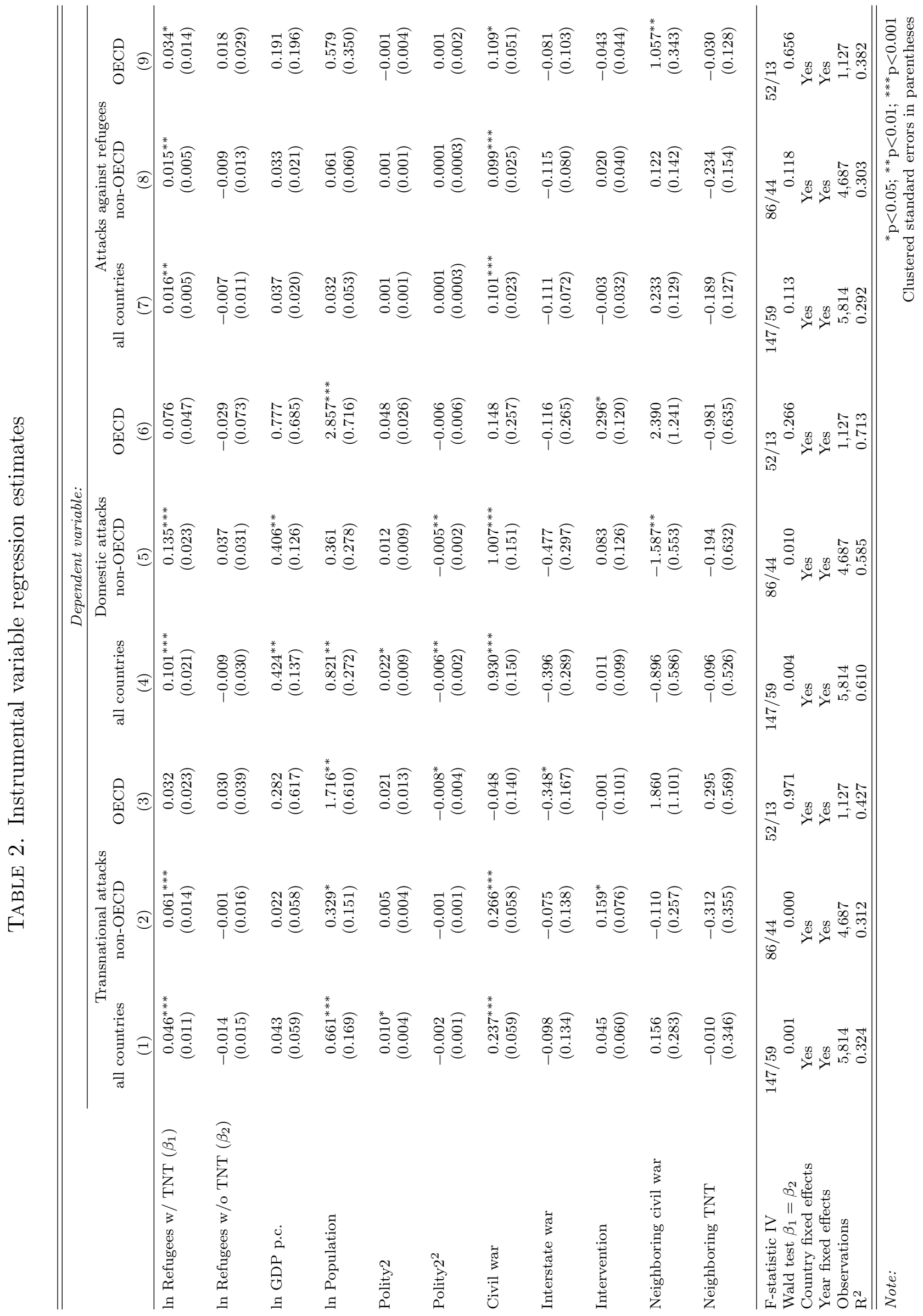


are systematically larger than other refugee stocks. If so, our results may be an artifact of the magnitude of refugee stocks. We therefore compare the distribution of the two variables. These are nearly identical, indicating that our results are unlikely to be driven by the sheer number of refugees (Figure A2).

Second, our results are robust to alternative measures of the dependent and key independent variables, specifically measures of terrorist fatalities capturing variation in the costs of terrorism (Table A7) and imputed refugee data from Marbach (Forthcoming) to check whether missing refugee values potentially bias the results (Table A8). All substantive conclusions remain unchanged. In addition, the results hold when restricting analyses to the post $9 / 11$ period (Table A9) and are robust to the inclusion of lagged dependent variables (Table A12-A13) ${ }^{32}$ Third, we explore alternative sender effects. Table A10 investigates whether diffusion is driven by Muslim vs. non-Muslim refugees. We find no evidence that transnational and domestic attacks are associated with Muslim refugees. However, refugees from majorityMuslim countries appear to increase the likelihood that refugees themselves become the targets of terrorist attacks in developed host countries. Table A11 examines the effect of civil wars in the refugee-sending country, showing that the presence of transnational terrorist organizations, and not the mere occurrence of civil war in the sending country, enables the diffusion of terrorism along our theoretical pathways.

Fourth, we show that our results can also be replicated using dyadic data (Table A14, Trojan Horse and Scapegoat pathway) and with count models (Table A15), hence they are not dependent on a specific estimation. Some may also wonder whether potential media reporting bias in developed countries can explain the findings. We note that this is unlikely. If terrorist attacks are more likely to be reported in developed countries, this should apply to all types of terrorist attacks, and especially those perpetrated by foreign actors (i.e. out-groups). If so, refugees should have a positive effect on all terrorist outcomes in developed countries, but this is not the case since refugees have no effect on the Trojan Horse and Copycat pathways.

${ }^{32}$ This setup induces "Nickel bias." 


\section{Conclusion}

In this article, we have provided the most rigorous analyses to date on the relationship between refugees and the diffusion of terrorism. Our evidence shows that current fears that accepting large numbers of refugees to Western countries will imply a direct import of terrorism from the sending countries are hardly warranted. According to our analyses, in developed countries refugee stocks do not constitute a Trojan horse that imports terrorism, nor do they boost homegrown terrorism. This does not mean that refugees can never generate security problems (they may do so in developing countries and in limited circumstances). However, the risk in Western countries is extremely low because these countries have already taken the necessary measures to effectively mitigate potential risks. Thus, our findings lend support to Angela Merkel's famous response to Europe's migration crisis: "Wir schaffen das" (We can do it) ${ }^{33}$ at least from a security viewpoint.

Rather than seeing refugees as perpetrators or vehicles of violence, this article has examined the targeting of refugees within a diffusion framework, whereby terrorism spreads to refugee-hosting country in the form of attacks against refugees. The finding that refugees are disproportionately likely to become the targets of attacks in host states due to fear or motivations for retaliation indicates that threat perceptions in Western countries are not only overblown (cf. Mueller 2006), but largely miss a key security problem: the security of refugees and migrants themselves. Thus, from a security perspective, the label "refugee crisis" is misleading or misdirected since refugees are the most likely victims. Inflation of the refugeeterrorism link through (social) media, politicians, as well as public authorities, unsettles the public needlessly; our evidence shows that, as a whole, refugees are hardly to blame for terrorism within the developed world. Although (some) politicians have incentives to stir hostility against refugees and migrants for electoral purposes, such forms of political pandering may generate major unintended consequences and trigger more terrorism.

There are a number of interesting questions for future research. Our analyses suggest that

33 http: //tinyurl.com/y4acme3o. 
psychological mechanisms based on fear, insecurity, and out-group antagonism can play a critical role in spreading terrorism to refugee-hosting countries, even in contexts where large scale civil violence is unlikely (i.e. developed countries). Future studies could explore what specific factors drive such fear, particularly to what extent domestic right-wing discourses, media frames, and emulation stoke hostility and even violence against refugees. We have also shown that developed countries are much less vulnerable to terrorist infiltrations. Future research should examine what specific characteristics account for this and explore variation in terrorism risk within the developed world. Moreover, countries differ in terms of restrictiveness of their migration policies as well as integration opportunities offered to migrants. Understanding how specific policy interventions influence the relationship between refugees and terrorism (including terrorism against refugees) is a critical next step for future research.

\section{References}

Allison, Paul D. 2009. Fixed effects regression models. SAGE.

Asal, Victor and Karl R Rethemeyer. 2008. "The Nature of the Beast: Organizational Structures and the Lethality of Terrorist Attacks." The Journal of Politics 70(2):437-449.

Atran, Scott. 2003. "Genesis of Suicide Terrorism.” Science 299(5612):1534-1539.

Bapat, Navin A. 2006. "State bargaining with transnational terrorist groups." International Studies Quarterly 50(1):213-229.

Bove, Vincenzo and Tobias Böhmelt. 2016. "Does Immigration Induce Terrorism?" The Journal of Politics 78(2):572-588.

Braithwaite, Alex. 2010. "Resisting infection: How state capacity conditions conflict contagion." Journal of Peace Research 47(3):311-319.

Braithwaite, Alex and Tiffany S. Chu. 2018. "Civil Conflicts Abroad, Foreign Fighters, and Terrorism at Home." Journal of Conflict Resolution 62(8):1636-1660.

Choi, Seung-Whan and Idean Salehyan. 2013. "No Good Deed Goes Unpunished: Refugees, Humanitarian Aid, and Terrorism." Conflict Management and Peace Science 30(1):53-75.

Docquier, Frédéric, Elisabetta Lodigiani, Hillel Rapoport and Maurice Schiff. 2016. "Emigration and democracy." Journal of Development Economics 120:209-223. 
Enders, Walter and Todd Sandler. 2011. "Who Adopts MIND/FIND in INTERPOL's Fight Against International Crime and Terrorism?" Public Choice 149(3):263-280.

Enders, Walter, Todd Sandler and Kusrav Gaibulloev. 2011. "Domestic versus Transnational Terrorism: Data, Decomposition, and Dynamics." Journal of Peace Research 48(3):319-337.

Europol. 2017. European Union Terrorism Situation and Trend Report $201 \%$.

URL: http://tinyurl.com/y8mnd4yx

Feyrer, James. Forthcoming. "Trade and Income-Exploiting Time Series in Geography." American Economic Journal: Applied Economics .

Fisk, Kerstin. 2018. "One-sided violence in refugee-hosting areas." Journal of Conflict Resolution 62(3):529-556.

Frankel, Jeffrey A and David H Romer. 1999. "Does trade cause growth?" American economic review 89(3):379-399.

Gaibulloev, Khusrav, James Piazza and Todd Sandler. Forthcoming. "Regime Types and Terrorism." International Organization .

Gleditsch, Nils Petter, Peter Wallensteen, Mikael Eriksson, Margareta Sollenberg and Håvard Strand. 2002. "Armed Conflict 1946-2001: A New Dataset." Journal of Peace Research $39(5): 615-637$.

Hewstone, Miles. 1990. "The 'ultimate attribution error'? A review of the literature on intergroup causal attribution." European Journal of Social Psychology 20(4):311-335.

Hoffman, Bruce. 2006. Inside Terrorism. New York, NY: Columbia University Press.

Huddy, Leonie, Stanley Feldman, Charles Taber and Gallya Lahav. 2005. "Threat, Anxiety, and Support for Antiterrorism Policies." American Journal of Political Science 49(3):593608.

Huddy, Leonie, Stanley Feldman and Christopher Weber. 2007. "The political consequences of perceived threat and felt insecurity." The ANNALS of the American Academy of Political and Social Science 614(1):131-153.

LaFree, Gary and Laura Dugan. 2007. "Introducing the global terrorism database." Terrorism and Political Violence 19(2):181-204.

Lischer, Sarah Kenyon. 2005. Dangerous Sanctuaries: Refugee Camps, Civil War and the Dilemmans of Humanitarian Aid. Ithaca, NY: Cornell University Press. 
Marbach, Moritz. Forthcoming. "On Imputing UNHCR Data." Research and Politics .

Mayer, Thierry and Soledad Zignago. 2011. "Notes on CEPII's distances measures: The GeoDist database.".

Milton, Daniel, Megan Spencer and Michael Findley. 2013. "Radicalism of the Hopeless: Refugee Flows and Transnational Terrorism." International Interactions 39(5):621-645.

Moore, Will H and Stephen M Shellman. 2007. "Whither will they go? A global study of refugees' destinations, 1965-1995." International Studies Quarterly 51(4):811-834.

Mueller, John E. 2006. Overblown: How politicians and the terrorism industry inflate national security threats, and why we believe them. Simon and Schuster.

Neumayer, Eric. 2004. "Asylum destination choice: what makes some West European countries more attractive than others?" European Union Politics 5(2):155-180.

Neumayer, Eric. 2005. "Bogus Refugees? The Determinants of Asylum Migration to Western Europe." International Studies Quarterly 49(3):389-409.

Neumayer, Erik and Thomas Plümper. 2010. "Galton's Problem and Contagion in International Terrorism along Civilizational Lines." Conflict Management and Peace Science $27(4): 308-325$.

Onoma, Ato Kwamena. 2013. Anti-refugee violence and African politics. Cambridge University Press.

Polo, Sara M.T. 2020. "How Terrorism Spreads: Emulation and the Diffusion of Ethnic and Ethnoreligious Terrorism." Journal of Conflict Resolution DOI 10.1177/0022002720930811.

Rüegger, Seraina and Heidrun Bohnet. 2018. "The Ethnicity of Refugees (ER): A new dataset for understanding flight patterns." Conflict Management and Peace Science 35(1):65-88.

Sageman, Marc. 2004. Understanding Terror Networks. Philadelphia, PA: University of Pennsylvania Press.

Salehyan, Idean and Kristian Skrede Gleditsch. 2006. "Refugees and the Spread of Civil War." International Organization 60:335-366.

Sanderson, Eleanor and Frank Windmeijer. 2016. "A weak instrument F-test in linear IV models with multiple endogenous variables." Journal of Econometrics 190(2):212-221. 
Sandler, Todd, Daniel G. Arce and Walter Enders. 2011. "An Evaluation of Interpol's Cooperative-Based Counterterrorism Linkages." The Journal of Law and Economics $54(1): 79-110$.

Savun, Burcu and Brian J Phillips. 2009. "Democracy, foreign policy, and terrorism." Journal of Conflict Resolution 53(6):878-904.

Savun, Burcu and Christian Gineste. 2019. "From protection to persecution: Threat environment and refugee scapegoating." Journal of Peace Research 56(1):88-102.

Schmid, Alex P. 2016. "Links between terrorism and migration." International Centre For Counter Terrorism (ICCT).

Skinner, Gideon and Glenn Gottfried. 2017. Global Views on the Immigration and the Refugee Crisis.

URL: http://tinyurl.com/yynk9eqs

Smith, Meagan and Sean M Zeigler. 2017. "Terrorism before and after 9/11-a more dangerous world?" Research \& Politics 4(4):2053168017739757.

Sovey, Allison J and Donald P Green. 2011. "Instrumental variables estimation in political science: A readers' guide." American Journal of Political Science 55(1):188-200.

UNHCR. 2016. "United Nations High Commissioner for Refugees. Population Statistics.".

URL: http://tinyurl.com/nj5rjd't

Whitaker, Beth Elise. 2003. "Refugees and the Spread of Conflict: Contrasting Cases in Central Africa." Journal of Asian and African Studies 38(2-3):211-231.

Wike, Richard, Bruce Stokes and Katie Simmons. 2016. Europeans fear wave of refugees will mean more terrorism, fewer jobs.

URL: http://tinyurl.com/y44gup37

Wooldridge, Jeffrey M. 2010. Econometric analysis of cross section and panel data. MIT press.

Wright, Thorin M. and Shweta Moorthy. 2018. "Refugees, Economic Capacity, and Host State Repression*." International Interactions 44(1):132-155. 


\section{Acknowledgements}

We thank the anonymous reviewers and the editor for their feedback as well as Aysegul Aydin, Bernd Beber, Alex Braithwaite, Olga Chyzh, Justin Esarey, Anna Getmansky, Macartan Humphreys, Graig Klein, Idean Salehyan, Burcu Savun and seminar participants at the University of Essex Workshop on Political Dissent: Causes, Tactics and Outcomes, the ISA Workshop on Modeling Spatial and Network Interdependence, Rice University IR seminar, Texas Triangle IR conference, the Peace Science Workshop on Refugees and Forced Migration, the Peace Research Institute Oslo, the Hertie School of Governance, the Peace Science Society, the Network of European Peace Scientists, and the American Political Science Association annual meetings for helpful comments and suggestions. We also thank Sophie Wellen for excellent research assistance.

\section{Biographical statements}

Sara M.T. Polo is Assistant Professor of Political Science at the University of Essex, Colchester, United Kingdom.

Julian Wucherpfennig is Professor of International Affairs and Security at the Hertie School, Berlin, Germany. 